\title{
Lannoitteiden tuontiin vaikuttavat tekijät
}

Hanna Partio

Helsingin yliopisto, Taloustieteen laitos, PL 27,00014 Helsingin yliopisto, hanna.partio@ helsinki.fi

\section{TIIVISTELMÄ}

Tutkimuksessa tarkastellaan lannoitteiden tuontiin vaikuttavia tekijöitä. Tutkimuksen kohteena ovat typpi- ja kaliumlannoitteiden tuontiin vaikuttavat tekijät kolmessa erityyppisessä maaryhmässä: 1) maat, joissa on korkea tulotaso 2) maat, joissa toteutettiin vihreä vallankumous vuosina 1965-1995 3) maat, joissa ei ole toteutettu vihreää vallankumousta. Lisäksi pyrittiin selvittämään, mitkä tekijät selittävät lannoitteiden tuonnin eroja eri maaryhmien välillä ja toisaalta, eroavatko tuontikysyntään vaikuttavat tekijät lannoitetyypeittäin maiden sisällä. Tutkimusmenetelmänä käytettiin ekonometristä estimointia ja analyysitekniikkana log-lineaarista regressiomallia.

Tutkimuksessa estimoitiin typpilannoitteista urean ja kaliumlannoitteista kaliumkloridin tuontikysyntä pääsääntöisesti vuodesta 1962 vuoteen 2009. Urean tuontikysyntämallit muodostettiin Yhdysvalloille, Brasilialle ja Togolle. Kaliumkloridin tuontikysyntämallit tehtiin Yhdysvalloille, Brasilialle ja Kamerunille. Lannoitteiden tuontia selittävät muuttujat olivat seuraavat: maan kansantalouden kehitys, lannoitteen maailmanmarkkinahinta, viljan maailmanmarkkinahinta, maan valuuttakurssi, viljelysmaa-ala asukasta kohti ja keinokastellun alueen osuus viljelysmaa-alasta.

Analyysissä havaittiin, että lannoitteiden tuontia selittävät muuttujat vaihtelevat sekä verrattaessa eri maita keskenään että lannoitetyypeittäin. Useiden tilastollisesti merkitsevien muuttujien joustot ovat verraten suuria, mikä viittaa siihen, että lannoitteiden tuonnin vaihtelut ovat melko joustavia selittävien muuttujien muutosten suhteen. Maissa, joissa ei ole toteutettu vihreää vallankumousta, mallit eivät selitä yhtä hyvin lannoitteiden tuontiin vaikuttavia tekijöitä.

Lannoitteiden ja viljan maailmanmarkkinahinnoilla ei havaittu olevan kovin suurta vaikutusta lannoitteiden tuontiin. Tämä osoittaa aiempien tutkimusten tavoin, että mm. valuuttakurssi kumoaa osan maailmanmarkkinahinnan vaikutuksesta eli maailmanmarkkinahinnalla on vain osittainen vaikutus tuontihintaan.

Tarkasteltaessa lannoitteiden tuontiin vaikuttavia tekijöitä, voidaan eri maaryhmien välillä havaita joitain selkeämpiä eroja. Korkean tulotason Yhdysvalloissa ja toisaalta vihreän vallankumouksen läpikäyneessä Brasiliassa urean ja kaliumkloridin tuontiin on vaikuttanut merkittävästi kansantalouden positiivinen kehitys. Lisäksi myös muut selittävät tekijät, kuten viljan hinta ja valuuttakurssi liittyvät vahvasti talouteen. Maissa, joissa ei ole toteutettu vihreää vallankumousta, merkittävin lannoitteiden tuontia selittävä muuttuja puolestaan on viljelysmaa-ala asukasta kohden.

Asiasanat: Lannoitteet, tuontikysyntä, ekonometrinen estimointi 


\section{Johdanto}

Maapallon väkiluku on yli kaksinkertaistunut 50 vuodessa. Maapallon ruoantuotanto on kasvanut vielä sitäkin nopeammin. Tähän on vaikuttanut etenkin 1960-luvulta lähtien toteutettu vihreä vallankumous, joka perustui paljolti kemiallisten lannoitteiden käytön yleistymiseen. Maailman lannoitteiden tuotanto on huomattavasti keskittyneempää kuin niiden kulutus.

Lannoitteiden tuonti ei ole jakautunut tasaisesti tuonnista riippuvaisten maiden välillä. Tähän vaikuttavat kansantalouden kehityksen lisäksi epäsuorasti myös muut sosioekonomiset tekijät ja koulutus ja tutkimus. Esimerkiksi Saharan eteläpuolinen Afrikka on kokonaisuudessaan lannoitteiden nettotuoja-alue. Sen tuontimäärät ovat kuitenkin minimaalisia verrattuna korkean tulotason maihin tai vihreän vallankumouksen läpikäyneisiin Aasian ja Etelä-Amerikan maihin.

Kasvavan viljan ja lihan kysynnän vuoksi maatalouden tuotosta halutaan kasvattaa. YK:n ja sen yhteistyötahojen tekemän selvityksen (The World Resources Institute 2013) mukaan maailma tarvitsee 70 prosenttia nykyistä enemmän ruokaa vuonna 2050. Jotta satotasoja voidaan lisätä, tarvitaan aiempaa enemmän myös lannoitteita. Lannoitteiden käytön tehostamista vaatii etenkin lannoiteriippuvaisten kasvien, kuten soijan, maissin ja vehnän viljely. Etenkin lannoitteiden tuojamaiden maataloustuotanto erityisen haavoittuva lannoitteiden maailmanmarkkinoiden muutoksille. On siis perusteltua tarkastella lannoitteiden tuontiin vaikuttavia tekijöitä.

Tutkimuksessa selvitetään, mitkä tekijät vaikuttavat lannoitteiden tuontiin ja eroavatko tuontikysyntään vaikuttavat tekijät kolmen eri maaryhmän välillä. Lisäksi tarkastellaan, eroavatko tuontikysyntään vaikuttavat tekijät eri lannoitetyyppien kohdalla Brasiliassa ja Yhdysvalloissa. Typpilannoitteita edustaa urea ja kaliumlannoitteita kaliumkloridi. Maaryhmät, joiden tuontikysyntää kummassakin lannoitetyypissä estimoidaan, on ryhmitelty seuraavasti: 1) korkean tulotason OECDmaat (The World Bank 2012a) 2) maat, joissa on toteutettu vihreä vallankumous vuosina 1965-1995 3) maat, joissa ei ole ollut vihreää vallankumousta (Saharan eteläpuolinen Afrikka).

\section{Aineisto ja menetelmät}

Tämän tutkimuksen tutkimusmenetelmänä on ekonometrinen estimointi. Tavoitteena on muodostaa yksinkertainen ekonometrinen malli lannoitteiden tuontikysyntään vaikuttavista tekijöistä. Analyysitekniikkana käytetään regressioanalyysiä, joka on yleisin ekonometriassa käytettävä malli (Davidson ja MacKinnon 2009, 1). Regressiomallissa pyritään selvittämään yhden tai useamman selittävän muuttujan (X) vaikutusta selitettävään muuttujaan (Y) (Ketokivi 2009, 86-87).

Regressiomallin ratkaisussa yleisimmin käytetty menetelmä on pienimmän neliösumman menetelmä (OLS). Menetelmä tuottaa sellaiset parametrien arvot, joilla minimoidaan residuaalien neliösummaa. Toisin sanoen pyritään siihen, että ero havainnon ja sen estimoidun arvon välillä on mahdollisimman pieni, jolloin mallin selittävyys paranee. Pienimmän neliösumman menetelmä sisältää oletuksen mallin lineaarisuudesta parametrien suhteen. Jos oletus ei päde, voidaan pienimmän neliösumman menetelmää edelleen käyttää muuttamalla malli log-lineaariseksi eli logaritmiseen muotoon. Log-lineaarinen malli tunnetaan myös vakiojoustomallina. Selittävien muuttujien kerroin $\beta_{\mathrm{j}}$ kuvaa niiden joustoa selitettävän muuttujan $Y_{\mathrm{i}}$ suhteen. Jousto määrittää, kuinka paljon selitettävä muuttuja muuttuu, kun selittävä muuttuja muuttuu yhdellä prosentilla. (Asteriou \& Hall 2007, 30-31; Gujarati 2004; Verbeek 2009, 55-57.)

Tässä tutkimuksessa päädyttiin käyttämään log-lineaarista funktiomuotoa lannoitteiden tuontikysynnän estimointiin. Alustava lannoitteiden tuontikysyntää kuvaava log-lineaarinen malli sisälsi seuraavat selittävät muuttujat: lannoitteen maailmanmarkkinahinta (USD/t), viljan

\footnotetext{
${ }^{1}$ Tässä tutkimuksessa vihreän vallankumouksen läpikäyneillä mailla tarkoitetaan Aasian ja Etelä-Amerikan maita, joissa satotasot ovat moninkertaistuneet vuosina 1965-1995.
} 
maailmanmarkkinahinta (USD/t), maan kansantalouden kehitys (BKT/asukas), maan valuuttakurssi, viljelysmaa-ala asukasta kohden ja kastellun maa-alan osuus kokonaisviljelymaa-alasta.

Tutkimuksen tutkimusaineisto koostuu useasta aikasarjasta. Tarkastelujaksona ovat vuodet 1962-2009. Poikkeuksia ovat Kamerun ja Togo, joiden kohdalla saatavilla ollut aineisto rajasi aikasarjaa. Kamerunin tuontiyhtälö muodostetaan vuosille 1980-2009 ja Togon vuosille 1977-2009.

Tuontiluvut on saatu FAO:n tilastopalvelusta (FAOSTAT 2012) kahdesta aikasarjasta (19612002 ja 2002-2009). Aikasarjojen suora yhdistäminen ei onnistu uuteen sarjaan tehtyjen muutosten vuoksi. Koska vuosi 2002 on tiedossa molemmissa aikasarjoissa, on uudempi sarja suhteutettu aiempaan aikasarjaan. Yhdysvaltojen kohdalla urean ja kaliumkloridin tuontiluvut vuodesta 2002 eteenpäin on saatu USA:n maatalousministeriön julkisesta tietokannasta (USDA 2012). Uudet luvut on niin ikään suhteutettu vanhempaan aikasarjaan.

Maiden kansantalouden kehitys, valuuttakurssit ja lannoitteiden sekä viljan maailmanmarkkinahinnat on saatu Maailmanpankin verkkotilastopalvelusta (The World Bank 2012b). Viljelysmaa-ala sekä kastellun viljelysmaan osuus kokonaisviljelymaa-alasta ovat saatu FAO:n tilastopalvelusta.

\section{Tulokset ja tulosten tarkastelu}

Lannoitteiden vuosittainen tuonti on vaihdellut suuresti etenkin Brasiliassa, Togossa ja Kamerunissa. Estimoinneissa päädyttiin käyttämään log-lineaarista funktiomuotoa lieventämään tätä vaihtelun voimakkuutta. Lisäksi alustavissa testiestimoinneissa havaittiin, että logaritmiset aikasarjat käyttäytyivät alkuperäisiä aikasarjoja paremmin.

Log-lineaariset mallit estimoitiin pienimmän neliösumman menetelmällä. Useat selittävät muuttujat olivat vahvasti korreloituneita, jonka vuoksi ainakin toinen keskenään korreloivista selittävistä muuttujista poistettiin. Kaikki yhtälöt sisälsivät autokorrelaatiota ja heteroskedastisuutta. Tällöin ei voida luottaa koko mallin merkitsevyyteen F-testillä tai kertoimien merkitsevyyteen ttestillä testattuina, sillä niiden tuottamat arvot voivat olla yliarvioituja. Autokorrelaatiota korjattiin estimoimalla mallit uudelleen Cochrane-Orcutt -menetelmän avulla. Heteroskedastisuutta pyrittiin poistamaan Whiten korjattuja keskivirhe-estimaatteja käyttämällä.

\section{Urean tuontikysyntää kuvaavat log-lineaariset mallit}

Taulukko 1. Brasilian urean tuontikysyntää kuvaavan log-lineaarisen mallin arvot

\begin{tabular}{lccc} 
Selittävä muuttuja & $\boldsymbol{\beta}$ & t-arvo & p-arvo \\
\hline Kansantalouden kehitys & 5.464847 & 2.202314 & $0.0331^{* *}$ \\
Viljan maailmanmarkkinahinta & -1.782904 & -2.557127 & $0.0142 * *$ \\
$\mathrm{C}$ & -30.65185 & -1.495843 & 0.1420 \\
$\mathrm{AR}(1)$ & 0.906449 & 13.99934 & 0.0000 \\
Selitysaste $\mathrm{R}^{2}$ & \multicolumn{2}{c}{ Vapausasteilla korjattu $\mathrm{R}^{2}$} & 0.840004 \\
F-testisuure & \multicolumn{2}{c}{ Durbin-Watson } & 1.589335 \\
$* * *(\mathrm{P}<0,01), * *(\mathrm{P}<0,05), *(\mathrm{P}<0,10)$ & & &
\end{tabular}

Brasilian urean tuontikysyntää kuvaava malli estimoitiin Cochrane-Orcutt -menetelmällä käyttämällä apuna Whiten korjattuja keskivirhe-estimaatteja (Taulukko 1$)$. Mallin selitysaste $\mathrm{R}^{2}(0,85)$ on hyvä ja testin mukaan malli selittää edelleen tuonnin vaihtelua alle prosentin riskitasolla. Durbin-Watson testisuure $(1,59)$ parani huomattavasti, mutta autokorrelaatiota esiintyy edelleen jonkin verran. Kansantalouden kehitys ja viljan maailmanmarkkinahinta ovat tilastollisesti merkitseviä urean tuontia selittäviä muuttujia alle viiden prosentin riskitasolla. Brasiliassa asukaskohtaisen BKT:n prosentin 
kasvu on lisännyt urean tuontia lähes 5,5 prosenttia vuosina 1962-2009. Viljan hinnan parametrin etumerkki on negatiivinen, jolloin viljan hinnannousu vähentää tuontia. Aikasarjoja tarkasteltaessa voidaan havaita, että viljan hintojen ja lannoitteiden tuonnin muutoksilla on ensimmäisinä vuosikymmeninä ollut vahva negatiivinen yhteys. Tähän on voinut vaikuttaa muun muassa tulotason alhaisuus, jolloin viljan hinnannousu on yksinkertaisesti vähentänyt ihmisten käytettävissä olevia tuloja vielä 1960- ja 1970-luvuilla.

Taulukko 2. Yhdysvaltojen urean tuontikysyntää kuvaavan log-lineaarisen mallin arvot

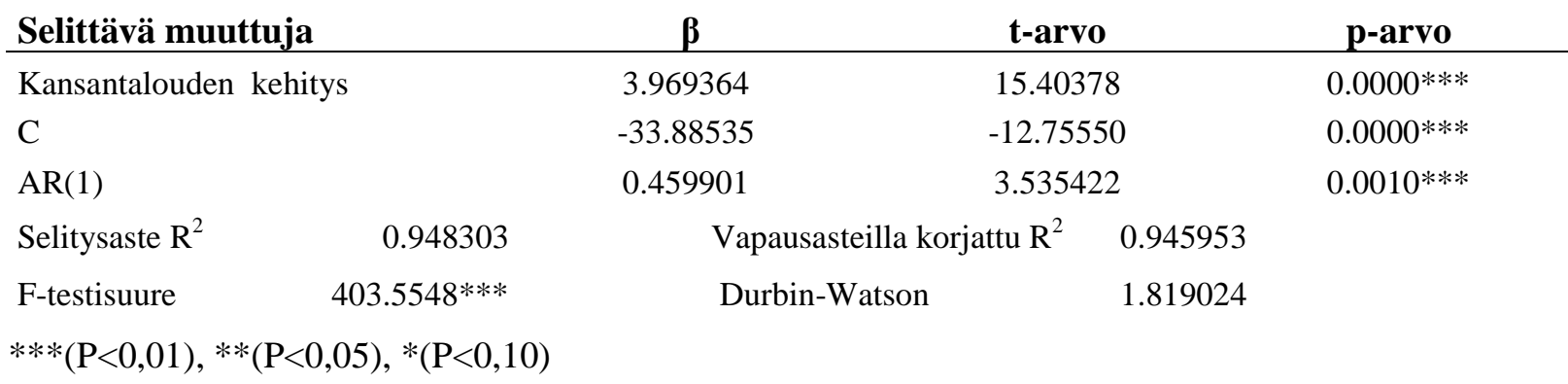

Yhdysvaltojen urean tuontikysyntää kuvaava malli estimoitiin Cochrane-Orcutt -menetelmällä käyttämällä apuna Whiten korjattuja keskivirhe-estimaatteja (Taulukko 2). Yhdysvaltojen estimoidun mallin selitysaste on 0,95 ja kansantalouden kehitys ja vakiokerroin olivat tilastollisesti merkitseviä tuontia selittäviä muuttujia alle prosentin riskitasolla. F-testin mukaan malli selittää urean tuonnin vaihtelua alle prosentin riskitasolla. Aikasarjoja tarkasteltaessa voidaan todeta parametrin kertoimen etumerkin olevan teorian ja oletusten mukainen. Tulotason nousu yhdellä prosentilla (BKT/asukas) lisää urean tuontia lähes neljä prosenttia.

Taulukko 3. Togon urean tuontikysyntää kuvaavan log-lineaarisen mallin arvot

\begin{tabular}{|c|c|c|c|c|}
\hline \multicolumn{2}{|c|}{ Selittävä muuttuja } & $\beta$ & t-arvo & p-arvo \\
\hline \multicolumn{2}{|c|}{ Kasteltu alue (/kokonais viljelysala) } & 1.786352 & 4.878330 & $0.0000 * * *$ \\
\hline \multicolumn{2}{|c|}{ Viljelysmaa-ala asukasta kohden } & 4.576061 & 2.229573 & 0.0340 ** \\
\hline \multicolumn{2}{|l|}{$\mathrm{C}$} & 13.77752 & 4.211086 & $0.0002 * * *$ \\
\hline \multicolumn{2}{|l|}{$\operatorname{AR}(1)$} & -0.112766 & -0.327626 & 0.7456 \\
\hline Selitysaste $\mathrm{R}^{2}$ & 0.307290 & Vapausasteilla korjattu $\mathrm{R}^{2}$ & 0.233071 & \\
\hline F-testisuure & $4.140326^{* *}$ & Durbin-Watson & 1.481518 & \\
\hline
\end{tabular}

Togon urean tuontikysyntää kuvaava malli estimoitiin Cochrane-Orcutt -menetelmällä käyttämällä apuna Whiten korjattuja keskivirhe-estimaatteja (Taulukko 3). Mallin selitysasteeksi saatiin 0,31 ja vapausasteilla korjatuksi selitysasteeksi 0,23 . Mallia testattiin muidenkin muuttujien kanssa, mutta keinokastelu ja viljelysmaa-ala olivat selittävistä muuttujista merkitsevimpiä. Keinokastelu ja vakiokerroin ovat merkitseviä alle yhden prosentin merkitsevyystasolla ja viljelysmaa-ala puolestaan alle viiden prosentin merkitsevyystasolla. F-testin mukaan malli selittää tuontia alle viiden prosentin riskitasolla. Durbin-Watson -testisuure ei ole kovinkaan hyvä, vaikka Cochrane-Orcutt -menetelmää on käytetty vähentämään autokorrelaatiota. Kaiken kaikkiaan voidaan todeta, että kyseisellä loglineaarisella mallilla selittävine muuttujineen ei onnistuta kuvaamaan Togon urean tuontia kovinkaan hyvin. 


\section{Kaliumkloridin tuontikysyntää kuvaavat log-lineaariset mallit}

Taulukko 4. Brasilian kaliumkloridin tuontikysyntää kuvaavan log-lineaarisen mallin arvot

\begin{tabular}{|c|c|c|c|}
\hline Selittävä muuttuja & $\boldsymbol{\beta}$ & t-arvo & p-arvo \\
\hline Kansantalouden kehitys & 2.762719 & 8.621886 & $0.0000 * * *$ \\
\hline Kaliumkloridin maailmanmarkkinahinta & -0.235276 & -1.460677 & 0.1515 \\
\hline Valuuttakurssi & 0.023108 & 4.125353 & $0.0002 * * *$ \\
\hline $\mathrm{C}$ & -13.86298 & -5.124069 & $0.0000 * * *$ \\
\hline $\operatorname{AR}(1)$ & 0.509323 & 4.277392 & $0.0001 * * *$ \\
\hline Selitysaste $\mathrm{R}^{2}$ & Vapausasteilla korjattu $\mathrm{R}^{2}$ & 0.973783 & \\
\hline $428.1430 * * *$ & Durbin-Watson & 2.011505 & \\
\hline
\end{tabular}

Estimoitu Brasilian kaliumkloridin tuontikysyntää kuvaava log-lineaarinen yhtälö on esitetty taulukossa 4. Malli pystyy selittämään lähes 98 prosenttia kaliumkloridin tuonnin vaihtelusta. Vapausasteilla korjattu selitysaste on 0,97. Muuttujakohtaiset t-testit osoittavat, että kansantalouden kehitys, valuuttakurssi ja vakiokerroin ovat tilastollisesti merkitseviä selittäviä muuttujia alle prosentin riskitasolla. Kaliumkloridin maailmanmarkkinahinta ei enää ollut tilastollisesti merkitsevä, mutta se päätettiin jättää malliin, sillä sen $\mathrm{p}$-arvo oli suhteellisen matala $(\mathrm{p}=0,15)$. Mallin selittävien muuttujien kerrointen etumerkit ovat kysyntäteorian mukaisia. Kansantalouden kehitys ja valuuttakurssi korreloivat positiivisesti ja kaliumkloridin hinta puolestaan negatiivisesti kaliumkloridin tuodun määrän kanssa.

Taulukko 5. Yhdysvaltojen kaliumkloridin tuontikysyntää kuvaavan log-lineaarisen mallin arvot

\begin{tabular}{|c|c|c|c|}
\hline Selittävä muuttuja & $\boldsymbol{\beta}$ & t-arvo & p-arvo \\
\hline Kaliumkloridin maailmanmarkkinahinta & -0.318401 & -1.363522 & 0.1800 \\
\hline Viljan maailmanmarkkinahinta & 0.358665 & 1.753099 & $0.0869^{*}$ \\
\hline Kansantalouden kehitys & 0.795867 & 1.758183 & $0.0860^{*}$ \\
\hline $\mathrm{C}$ & -0.022265 & -0.004736 & 0.9962 \\
\hline $\mathrm{AR}(1)$ & 0.781533 & 18.96881 & $0.0000 * * *$ \\
\hline Selitysaste $\mathrm{R}^{2}$ & Vapausasteilla korjattu $\mathrm{R}^{2}$ & 0.906887 & \\
\hline $113.0055^{* * *}$ & Durbin-Watson & 2.046189 & \\
\hline
\end{tabular}

Yhdysvaltojen kaliumkloridin tuontikysyntää kuvaava malli estimoitiin Cochrane-Orcutt menetelmällä käyttämällä apuna Whiten korjattuja keskivirhe-estimaatteja (Taulukko 5). F-testin mukaan malli onnistuu kuvaamaan selitettävän muuttujan vaihtelua alle yhden prosentin riskitasolla. Muuttujien välillä ei ole haitallista korrelaatiota, joten multikollineaarisuutta ei enää esiinny. DurbinWatson -testisuureen arvo on hyvä eikä se viittaa autokorrelaatioon. Kuitenkin mallin ainoat tilastollisesti merkitsevät muuttujat ovat kansantalouden kehitys ja viljan hinta alle kymmenen prosentin riskitasolla. Kaliumkloridin maailmanmarkkinahinta päätettiin jättää malliin, sillä muuttujan p-arvo $(0,18)$ on suhteellisen alhainen. Mallin estimoimisen yhteydessä kokeiltiin erilaisia muuttujayhdistelmiä, joista ainoastaan yllä oleva tuotti ratkaisun. Tulos jättää kuitenkin epäilyn siitä, että malli ei tosiasiassa onnistu kuvaamaan kovinkaan hyvin kaliumkloridin tuontiin vaikuttavia tekijöitä Yhdysvalloissa. 
Taulukko 6. Kamerunin kaliumkloridin tuontikysyntää kuvaavan log-lineaarisen mallin arvot

\begin{tabular}{lccc} 
Selittävä muuttuja & $\boldsymbol{\beta}$ & t-arvo & p-arvo \\
\hline Viljelysmaa-ala asukasta kohden & -1.848361 & -2.358777 & $0.0265^{* *}$ \\
Valuuttakurssi & 0.927940 & 1.823798 & $0.0802^{*}$ \\
$\mathrm{C}$ & -5.033645 & -1.809228 & $0.0825^{*}$ \\
$\mathrm{AR}(1)$ & 0.262786 & 1.409550 & 0.1710 \\
Selitysaste $\mathrm{R}^{2}$ & 0.594363 & Vapausasteilla korjattu $\mathrm{R}^{2}$ & 0.545686 \\
F-testisuure & $12.21046^{* * *}$ & Durbin-Watson & 2.094134 \\
$* * *(\mathrm{P}<0,01), * *(\mathrm{P}<0,05), *(\mathrm{P}<0,10)$ & &
\end{tabular}

Kamerunin kaliumkloridin tuontikysyntää kuvaava malli estimoitiin Cochrane-Orcutt -menetelmällä käyttämällä apuna Whiten korjattuja keskivirhe-estimaatteja (Taulukko 6). Estimoitu malli selittää noin 60 prosenttia kaliumkloridin tuonnin vaihtelusta. F-testin mukaan malli onnistuu kuvaamaan tuonnin vaihtelua alle yhden prosentin riskitasolla. Muuttujien välillä ei ole haitallista korrelaatiota, joten multikollineaarisuutta ei enää esiinny. Durbin-Watson -testisuureen arvo on hyvä eikä se viittaa autokorrelaatioon.

\section{Johtopäätökset}

Lannoitteiden tuontia selittävät muuttujat vaihtelivat ensinnäkin vertailussa eri maiden välillä, mutta toisaalta myös urean ja kaliumkloridin välisessä vertailussa. Koska tilastollisesti merkitsevien muuttujien joustot ovat pääosin yli yhden, viittaa tämä siihen, että lannoitteiden tuonnin vaihtelut ovat melko joustavia selittävien muuttujien muutosten suhteen.

Tarkasteltaessa eroja lannoitteiden tuontiin vaikuttavissa tekijöissä eri maaryhmien välillä, voidaan ryhmien välillä havaita joitain eroavaisuuksia. Korkean tulotason Yhdysvalloissa ja vihreän vallankumouksen läpikäyneessä Brasiliassa on urean ja kaliumkloridin tuontiin vaikuttanut merkittävästi kansantalouden suotuisa kehitys. Lisäksi myös muut selittävät tekijät, kuten viljan maailmanmarkkinahinta ja valuuttakurssi, liittyvät vahvasti talouteen. Sen sijaan maissa, joissa ei ole ollut vihreää vallankumousta (Togo ja Kamerun), merkittävin selittävä muuttuja on puolestaan viljelysmaa-ala asukasta kohden. Tämän perusteella voidaan karkeasti yleistäen todeta, että kansantaloudelliset ja markkinavetoiset muuttujat - kuten kansantalouden kehitys, valuuttakurssi ja hinnat - vaikuttavat lannoitteiden tuontiin eniten korkean ja keskitulotason maissa. Togossa ja Kamerunissa BKT:n kasvu ei vaikuta juurikaan lannoitteiden kysyntään. Voidaankin olettaa, että näissä maissa ei ole vielä päästy sille kansantalouden ja talouskasvun tasolle, jossa suurempi osa tuloista käytettäisiin maataloustuotannon kannalta tärkeisiin tuotantopanoksiin. Tällä hetkellä valtaosa tulojen kasvusta käytetään ruokaan ja muihin välttämättömyyshyödykkeisiin.

Maissa, joissa ei ole toteutettu vihreää vallankumousta, mallit selittävät heikommin lannoitteiden tuontiin vaikuttavia tekijöitä. Togon ja Kamerunin tuontia kuvaavien mallien selitysasteet ovat keskimäärin alhaisempia, kuin kahdessa muussa maaryhmässä, joten mallin sisältämät muuttujat onnistuvat kuvaamaan tuonnin muutoksia vain osin. Aiempien tutkimusten perusteella voidaan kuitenkin päätellä, että Saharan eteläpuolisessa Afrikassa lannoitteiden tuontiin vaikuttavat mallin sisältämien muuttujien lisäksi muun muassa kuljetus- ja jakelukustannukset sekä erilaiset sosioekonomiset ja kulttuuriset tekijät (Bumb 2011; Chembezi 1989; FAO/IFA 1999).

Lannoitteiden maailmanmarkkinahinnoilla ei havaittu olevan vaikutusta lannoitteiden tuontiin alle kymmenen prosentin riskitasolla. Tämä osoittaa aiempien tutkimusten tavoin sen, että valuuttakurssin muutos kumoaa osan maailmanmarkkinahinnan vaikutuksesta eli maailmanmarkkinahinta on vain osa tuontihintaa. Näin on erityisesti Saharan eteläpuolisessa Afrikassa, jossa lannoitteen hintajousto on lisäksi hyvin joustamatonta. (Alemu ym. 2011; Carter ym. 1990; Takeshima ja Lee 2012; Yeboah ym. 2009). 
Maan sisäisiä eroja urean ja kaliumkloridin tuonnissa voitiin tarkastella Brasiliassa ja Yhdysvalloissa. Brasiliassa merkittävin urean ja kaliumkloridin tuontia selittävä tekijä on ollut kansantalouden kehitys. Maan kaliumkloridin tuontiin on vaikuttanut lisäksi valuuttakurssi. Brasilian kaliumkloridin kulutus on lähes täysin tuonnin varassa, joten on luonnollista, että maan valuuttakurssilla on vaikutusta lannoitteen tuontiin.

Myös Yhdysvalloissa kansantalouden kehitys vaikuttaa sekä urean että kaliumkloridin tuontiin. Tulojousto on joustavaa urean suhteen $(3,97)$ ja joustamatonta kaliumkloridin suhteen $(0,8)$. Kaliumkloridin kulutus oli suhteellisen suurta jo 1960-luvulla, joten kansantalous ja kaliumkloridin tuonti ovat kasvaneet lähes samassa suhteessa viimeisen 50 vuoden aikana. Urean tuonti ja kulutus olivat kaliumkloridiin verrattuna pientä 1960-luvulla, minkä seurauksena urean tuonti on moninkertaistunut suhteessa kansantalouden kasvuun 2000-luvulle tultaessa. Lisäksi urean tuonti oli varsin vaatimatonta 1980-luvulle saakka, joten 1970-luvun lopun taloudelliset notkahdukset eivät vaikuttaneet urean tuontiin kaliumkloridin tavoin. Kaliumkloridin kohdalla tuontiin vaikuttaa lisäksi lannoitteen viljan maailmanmarkkinahinta $(0,36)$. Kaliumkloridi on käyttömäärään suhteutettuna USA:n tuoduin lannoite.

\section{Kirjallisuus}

Alemu, Z. G., Jooste, A. ja Louw, C. 2011. Price transmission between international and local fertilizer prices: the case of South Africa. Paper prepared for presentation at the 21st annual food and agribusiness management (IFAMA) symposium: $18 \mathrm{~s}$.

Asteriou, D. ja Hall, S. G. 2007. Applied Econometrics - A Modern Approach using EViews and Microfit. Revised Edition. New York: Palgrave Macmillan. 407 s.

Bump, B. L., Johnson, M. E. ja Fuentes, P. A. 2011. Policy Options for Improving Regional Fertilizer Markets in West Africa. IFPRI Discussion Paper 01084. Washington, DC, IFPRI: 84 s.

Carter, C. A. 1989. Wheat Inputs and the Law of One price. Agribusiness 5: 489-457.

Chembezi, D. M. 1989. Estimating Fertilizer Demand and Output Supply for Malawi's Smallholder Agriculture. Agricultural Systems 33, 292-314.

Davidson, R. ja Mackinnon, J. G. 2009. Econometric Theory and Methods. International Edition. New York, Oxford University Press. $750 \mathrm{~s}$.

FAO (Food and Agriculture Organization of the United Nations) /IFA (International Fertilizer Industry Association). 1999. Fertilizer Strategies. Rome, FAO: 111 s.

FAOSTAT. 2012. Statistics. Rome, FAO.

Gujarati, D. 2004. Basic Econometrics. 4th edition. The McGraw-Hill Companies. 1002 s.

Ketokivi, M. 2009. Tilastollinen päättely ja tieteellinen argumentointi. Helsinki: Gaudeamus. $251 \mathrm{~s}$.

Takeshima, H. ja Lee, H. L. 2012. Agricultural Inputs Subsidy and Their Developmental Impact: Conventional Wisdom. IFPRI Policy Note 1, October 2012. Washington DC, IFPRI: 4 s.

The World Bank. 2012a. Country classifications: High-income OECD members. Saatavilla: http://data.worldbank.org/about/country-classifications/country-and-lending-groups\#OECD_members.

The World Bank. 2012b. Data: Global Economic Monitor (GEM) Commodities, World Development Indicators. Saatavilla: http://data.worldbank.org/.

The World Resources Institute. 2013. Creating a Sustainable Food Future: A menu of solutions to sustainably feed more than 9 billion people by 2050. Washington, DC, The World Resources Institute: $154 \mathrm{~s}$.

United States Department of Agriculture. 2012. Data Sets: Fertilizer Imports/Exports. USDA Economic Research Service.

Verbeek, M. 2008. A Guide to Modern Econometrics. 3rd Edition. England, John Wiley \& Sons, Ltd.

Yeboah, O., Shaik, S. ja Allen, A. 2009. Exchange Rates Impacts on Agricultural Inputs Prices using VAR. Journal of Agricultural and Applied Economics 41: 511-520. 